\title{
PENGGUNAKAN METODE KOOPERATIF LEARNING PADA MATERI ASEAN IPS SEKOLAH DASAR UNTUK MENINGKATKAN HASIL BELAJAR
}

\author{
Loecita Sandiar*, Dwi Narsih** \\ Universitas Indraprasta PGRI Jakarta \\ *loecitasandiar@gmail.com \\ *dwinpunya@gmail.com
}

\begin{abstract}
The purpose of this Classroom Action Research (CAR) was carried out with the aim to find out the increase in social studies learning achievements of ASEAN material through the application of cooperative learning methods to class VI SDN Jatiasih Bekasi students in 2018/2019. This Classroom Action Research was carried out by applying the Jigsaw type cooperative learning model in order improve the quality of the learning process and is a concept of learning activities that help teachers in carrying out mathematics learning activities on fractions taught by trying to maximize the active role of students, especially the knowledge they have and how they are applied in everyday life. With this concept, learning outcomes are expected to be more meaningful for students. The learning process takes place naturally in the form of activities students work and experience, not transfer knowledge from teacher to student. The quality of learning is more important than learning outcomes. Classroom Action Research (CAR) is carried out in stages 2 cycles, and the results of the actions taken have been proven to be able to improve student learning outcomes / achievements in terms of classical student mastery learning in the first cycle of 53\%, could increase to $74.5 \%$ in the second cycle and in terms of the average value of the evaluation results of 74.5 in the second cycle of 79.2, this means there is an increase of 22\%. From the results of this class action research also showed an increase in the level of student learning activities from 3 categories Active Enough in the first cycle to 3.5 Active categories, Active categories in the second cycle to 3.8 categories Very Active means there was an increase of $28.5 \%$.
\end{abstract}

Keywords: Learning Model, cooperative learning methods, Learning Achievement

\begin{abstract}
Abstrak: Tujuan penelitian Tindakan Kelas ( PTK) ini dilakukan dengan tujuan untuk mengetahui peningkatan prestasi belajar IPS materi ASEAN melalui penerapan metode kooperatif learning pada siswa kelas VI SDN Jatiasih Bekasi tahun 2018/2019. Penelitian Tindakan Kelas ini dilakukan dengan menerapkan model pembelajaran kooperatif tipe Jigsaw dalam rangka meningkatkan kualitas proses pembelajaran dan merupakan sebuah konsep kegiatan pembelajaran yang membantu guru dalam melaksanakan kegiatan pembelajaran matematika pada materi pecahan yang diajarkan dengan berusaha memakasimalkan peran aktif siswa terutama
\end{abstract}


pengetahuan yang dimilikinya dan bagaimana penerapannya dalam kehidupan seharihari. Dengan konsep itu, hasil pembelajaran diharapkan lebih bermakna bagi siswa. Proses pembelajaran berlangsung alamiah dalam bentuk kegiatan siswa bekerja dan mengalami, bukan mentransfer pengetahuan dari guru ke siswa. Kualitas pembelajaran pembelajaran lebih dipentingkan daripada hasil. Penelitian Tindakan Kelas ( PTK ) ini dilakukan dalam tahapan 2 siklus, dan dari hasil tindakan yang sudah dilakukan terbukti dapat meningkatkan hasil/prestasi belajar siswa baik dari segi ketuntasan belajar siswa secara klasikal yaitu pada siklus I sebesar $53 \%$, dapat meningkat menjadi 74,5\% pada siklus II maupun dari segi nilai rata-rata hasil evaluasi 74,5 pada siklus II sebesar 79,2, ini berarti ada peningkatan sebesar $22 \%$. Dari hasil penelitian tindakan kelas ini juga menunjukkan adanya peningkatan tingkat aktivitas belajar siswa dari 3 kategori Cukup Aktif pada siklus I menjadi 3,5 kategori Aktif, kategori Aktif pada siklus II menjadi 3,8 kategori Sangat Aktif berarti ada peningkatan sebesar 28,5\%

Kata Kunci: Model Pembelajaran, Metode Kooperatif Learning, Prestasi Belajar

\section{PENDAHULUAN}

Berbagai persoalan pendidikan di Indonesia masih hangat untuk dibicarakan. Beberapa masalah yang sering muncul adalah mutu pendidikan, perubahan kurikulum, sarana dan prasarana pendidikan, sistem evaluasi, sertifikasi guru, dan masalah-masalah lain yang menjadi proses belajar mengajar. Lebih khusus tentang pembelajaran, hendaknya proses pembelajaran merupakan berrkomunikasi dan bersosialisasi yang akhirnya menimbulkan suatu kerja sama yang sehat khususnya dalam lingkup kelas. Persoalan metode pembelajaran merupakan suatu dinamika kehidupan guru dan murid di sekolah. Masalah itu tidak akan pernah habis untuk dikupas dan tidak pernah tuntas dibahas.Bimbingan dan pengawasan guru masih diperlukan, tetapi intervensi terhadap kegiatan siswa dalam pemecahan masalah harus dikurangi . Maka dari itu, guru hendaknya dapat menajar secara dengan professional, demekian juga dengan murid-murid, setiap tahun berganti murid, masalah yang dihadapi guru akan berbeda pula. Salah satu masalah yang juga menarik untuk segera ditangani secara mendalam salah satunya adalah metode pembelajaran di dalam kelas. Salah satu metode yang mendukung interaksi antar siswa, yang dapat menimbulkan kerja sama yang sehat itu adalah metode pembelajaran kooperatif learning. Metode 
ini diyakini dapat meningkatkan hasil pembelajaran ${ }^{1}$.Selanjutnya, pelajaran IPS ,sebagai mata pelajaran yang dijarkan di SD, merupakan pelajaran yang lebih menekankan bidang ilmu sosial. Diharapkan siswa memiliki kemampuan dasar untuk berpikir logis dan kritis, rasa ingin tahu, inkuiri, memecahkan masalah, dan keterampilan sosial dalam kehidupan sosial' ${ }^{2}$. Mata pelajaran IPS, mempunyai peran yang penting dalam kehidupan bermasyarakat dan bernegara namun pada pembelajran di kelas, kadang menimbulkan beberapa kendala. Karena bersifat hafalan, pembelajaran IPS menjadi menjemukan, tidak menarik dan dipandang sebagai beban bagi peserta didik, apalagi kalau dikaitkan dengan statusnya sebagai mata pelajaran yang tidak di-UN-kan. Masyarakat pun memandang bahwa pelajaran IPS itu tidak penting, di samping tidak di-UN-kan, juga tidak banyak manfaatnya dalam kehidupan keseharian. Pelajaran IPS tidak dapat mendatangkan uang, pelajaran IPS tidak bisa untuk membangun rumah, tidak bisa untuk membangun jembatan, dan seterusnya.

Aliran positivisme dan paham materialisme yang berkembang telah ikut memperkokoh pandangan masyarakat itu. Hal-hal yang tidak observable, dan tidak terukur cenderung diabaikan atau tidak dikembangkan. Uraian tersebut memberikan petunjuk bahwa pembelajaran (sebagai realisasi dari penyelenggaraan pendidikan) yang berorientasi pada materi ajar, menjadi kurang bermakna bagi hidup dan kehidupan warga belajar. Pembelajaran yang mengutamakan penguasaan materi ajar seperti yang selama ini terjadi, cenderung mengabaikan nilai-nilai moral dan pengembangan karakter peserta didik. Pembelajaran yang mengabaikan pengembangan karakter telah kehilangan ruh dan esensinya sebagai proses pendidikan yang sesungguhnya, yakni sebuah proses untuk mencerdaskan kehidupan berbangsa dan bernegara bagi masyarakat agar menjadi bangsa yang lebih bermartabat. Begitu juga pembelajaran IPS telah kehilangan ruhnya sebagai proses pendidikan yang dapat memberikan sumbangsih terhadap pendidikan karakter bangsa, yakni untuk membentuk warga negara yang baik, warga negara yang memiliki

\footnotetext{
${ }^{1}$ Juita, H. R., \& Widiyarto, S. (2019, March). The Effectiveness of Cooperative Learning Methods: A case study of writing learning at Junior High School. In Second Conference on Language, Literature, Education, and Culture (ICOLLITE 2018)

2 Permen Pendidikan Nasional Nomor 22 tahun 2007
} 
kearifan dan keterampilan sosial, serta warga negara yang sadar akan jati dirinya sebagai bangsa.

Selanjutnya hasil belajar merupakan salah satu tolak ukur belajar agar ada perubahan tingkah laku sebagai proses belajar yang meliputi kognitif, afektif, dan psikomotor. Hasil belajar merupakan produk, keterampilan, dan sikap yang tercermin di dalam perilaku sehari-hari ${ }^{3}$. Selanjutnya hasil belajar adalah penilaian pendidikan tentang kemauan siswa yang berkenaan dengan materi pelajaran yang telah dikuasai ${ }^{4}$. Hasil belajar tidak akan pernah diperoleh selama seseorang tidak melakukan kegiatan pembelajaran. Dengan demikian untuk memperoleh hasil belajar siswa harus melakukan kegiatan pembelajaran.

Berdasarkan uraian diatas peneliti, akan melakukan penelitian penggunakan metode kooperatif learning pada materi ASEAN IPS di SDN Jatiasih II Bekasi.

\section{METODE DAN PENDEKATAN PENELITIAN}

Penelitian ini dilaksanakan di SDN Jatiasih II Bekasi. Subjek dalam penelitian ini adalah seluruh siswa kelas VI SDN yang berjumlah 30 orang yang terdaftar pada tahun ajaran 2018/2019. Metode yang digunakan dalam penelitian ini adalah pembelajaran kooperatif. adalah metode pembelajaran menitik beratkan kerjasama dalam mencapai hasil pembelajaran yang maksimal. Jenis data yang didapatkan dalam penelitian ini adalah data kualitatif dan kuantitatif.

1. Data kualitatif yaitu data yang diperoleh dari aktivitas siswa dan akivitas guru berupa data hasil observasi dan hasil wawancara.

2. Data kuantitatif yaitu data yang diperoleh hasil tes yang diberikan kepada siswa $^{5}$

Teknik pengumpulan data dalam penelitian tindakan kelas ini berupa data kuantitatif, yaitu data yang diperoleh dari hasil tes pekerjaan siswa dalam mengerjakan tugas dan observasi kagiatan yang yang dilakukan selama pelaksanaan proses belajar mengajar.

\footnotetext{
${ }^{3}$ Ibrahim, M. 2005. Asesmen Berkelanjutan. Surabaya: Unesa University Press

${ }^{4}$ Winkel, WS. 1996. Psikologi Pengajaran. Edisi Revisi. Jakarta: Grasindo

${ }^{5}$ Sugiono. (2010). Metode Penelitian Kuantitatif, Kualitatif. Bandung: Alfabeta
} 
Teknik analisa data yang digunakan adalah model alur, yaitu reduksi data, penyajian data, dan penarikan kesimpulan, Milles \& Huberman ${ }^{6}$

Adapun teknik pengumpulan data adalah sebagai berikut :

1. Teknik Analisis Kualitatif

Analisa data dalam penelitian ini dilakukan setelah pengumpulan data.

Adapun tahap-tahap kegiatan analisis data kualitatif adalah: 1) mereduksi data,

2) menyajikan data, 3) penarikan kesimpulan dan verifikasi.

2. Teknik Analisis data Kuantitatif

Teknik analisa data kuantitatif yang digunakan dalam Penelitian Tindakan Kelas (PTK) ini adalah hasil belajar. Dengan demikian akan ditentukan indikator hasil belajar siswa. Indikator dapat digunakan sebagai dasar keberhasilan belajar siswa, dan menjadi catatan perbaikan pembelajaran berikutnya. Berdasarkan indikator hasil belajar siswa dapat dilihat pada bagian observasi untuk siswa di atas, lalu ditentukan frekuensinya atau jumlah siswa, kemudian dihitung berdasarkan rumus presentase ketuntasan belajar siswa dengan menggunakan rumus sebagai berikut :

a. Daya serap individu (\%) DSI

$$
\text { DSI }=\frac{\text { skor yang diperoleh siswa }}{\text { skor maks siswa }} \times 100 \%
$$

b. Ketuntasan belajar klasikal (\%)

$$
\mathrm{KBK}=\frac{\text { banyaknya siswa yang tuntas }}{\text { banyak siswa seluruhnya }} \times 100 \%
$$

c. Rata-rata

$$
\text { Rata-rata }=\frac{\text { Nilai Perolehan Seluruh Siswa }}{\text { Jumlah Siswa Keseluruhan }} \times 100 \%
$$

Indikator kualitatif pembelajaran dapat dilihat dari aktivitas siswa dan guru. Penelitian ini dikatakan berhasil jika aktivitas siswa dan guru telah berada dalam kategori baik atau sangat baik. Dengan kriteria sebagai berikut :

a. Sangat Baik (SB) rentang nilai $90-100$;

b. Baik (B) rentang nilai $70-89$;

c. Cukup (C) rentang nilai 45 - 69;

d. Kurang $(\mathrm{K})$ dengan rentang nilai 45 ke bawah.

\footnotetext{
${ }^{6}$ Sudjana, dkk. 1989. Pedoman Praktek Mengajar. Bandung; Depdikbud
} 


\section{HASIL PENELITIAN DAN PEMBAHASAN}

Penelitian tindakan kelas (PTK) yang dilakukan di SDN Jatiasih pada siswa kelas VI yang berjumlah 30 orang. Penelitiantindakan kelas ini bertujuan untuk meningkatkan hasil belajar pelajaran IPS, pada materi ASEAN.

\section{Hasil Sebelum Tindakan}

Sebelum peneliti melakukan tindakan dengan menggunakan metode kooperatif learning, terlebih dahulu peneliti melakukan pra tindakan yang bertujuan untuk mengetahui tingkat kemampuan siswa tentang materi ASEAN dengan aspek-aspek penilaian tertentu.

Berdasarkan hasil dari pra tindakan awal yang diikuti 30 perserta yang mengikuti tes, hanya diperoleh 11 siswa yang dinyatakan tuntas belajar. Perolehan ketuntasan belajar klasikal sebesar 41,61\% dan daya serap klasikal sebesar 60,16\% dengan persentase nilia rata-rata diperoleh sebesar 63\%. Dari hasil perolehan yang didapatkan tersebut, masih berada pade kategori cukup. Hal inilah yang menjadi tolok ukur dan dasar peneliti untuk melakukan upaya perbaikan dalam rangka peningkatan hasil belajar siswa, khususnya dalam pelaksanaan pembelajaran IPS pada materi ASEAN.

\section{Hasil Penelitian Siklus I}

Dalam proses belajar mengajar diamati melalui aspek-aspek siswa memberikan tanggapan saat guru memberikan apersepsi, Siswa mendengarkan penjelasan materi yang disampaikan oleh guru, Siswa mengamati dan memahami LKS, Siswa berdiskusi dengan kelompok, dan kemampuan siswa dalam memahami materi ASEAN dan segala aspek pengetahuan yang lain.

Berdasarkan hasil siklus I pertemuan I, menunjukkan aktivitas siswa dalam kegiatan belajar mengajar pada siklus I pertemuan I diperoleh jumlah persentase ratarata 2,01 $\%$ dan pada siklus I pertemuan II, diperoleh rata - rata presentase 2,27 \% berdasarkan kriteria yang telah ditetapkan menunjukan bahwa aktivitas belajar siswa berada pada kategori Kurang sehingga perlu ditingkatkan melalui proses pembelajaran pada siklus selanjutnya.

Untuk mengukur aktifitas guru selama pelaksanaan proses pembelajaran yang diukur oleh mitra kolaborator melalui proses pengamatan terhadap aktifitas guru dalam kegiatan mengajarnya dilakukan dengan lembar observasi pengamatan yang telah dipersiapkan. Berdasarkan hasil observasi aktivitas guru dalam kegiatan belajar 
mengajar pada siklus I pertemuan I berada pada presentase 46,5\%. Pada siklus I pertemuan II diperoleh rata-rata presentase 60,5 \% atau berada pada kriteria Kurang sesuai dengan kriteria yang telah ditetapkan dalam penelitian ini. Dengan demikian aktivitas guru dalam kegiatan pembelajaran perlu ditingkatkan pada siklus selanjutnya. Untuk mengukur kemampuan pemahaman materi dilakukan melalui tes secara lisan dengan menggunakan peta negara- negara ASEAN. Adapun aspek-aspek yang di nilai adalah sejarah berdirinya ASEAN, tujuan ASEAN, kerjasma antar negar ASEAN dan anggota negara negara ASEAN. Selanjutnya aspek - aspek yang telah di nilai ditabulasi berdasarkan rumus perhitungan yang telah ditetapkan sebelumnya. Pada hasi tes akhir tindakan siklus I menunjukan bahwa dalam kegiatan pembelajaran IPS kemampuan materi dengan metode kooperatif learning yang diikuti oleh 30 perserta yang mengikuti tes, hanya diperoleh 21 siswa yang dinyatakan tuntas belajar. Perolehan ketuntasan belajar klasikal sebesar 67,75\% daya serap klasikal sebesar 66,5\% dengan persentase nilai rata-rata sebesar 67,47 dan berada pade kategori cukup.

Dengan demikian kemampuan peserta didik dalam menerima materi saat proses pembelajaran pemahaman menggunakan Pembelajaran ternyata telah terjadi peningkatan dari sebelum dilaksanakannya tindakan dimana peningkatan presentase sebesar 26,14\% pada siklus I. Namun dari peningkatan tersebut indikator kinerja yang telah ditetapkan belum terpenuhi yaitu $80 \%$ secara klasikal. Untuk rata-rata ketuntasan individu belum tercapai sebab belum mencapai 70. Berdasarkan pengolahan tersebut maka perlu diadakan tindak lanjut terhadap pelaksanaan proses pembelajaran melalui proses tindakan pada siklus II.

\section{Hasil Penelitian Siklus II}

Hasil observasi aktivitas siswa dalam proses belajar mengajar pada siklus II diamati melalui aspek-aspek siswa memberikan respon saat guru memberikan apersepsi, Siswa mendengarkan penjelasan materi yang disampaikan oleh guru, Siswa mengamati dan memahami LKS, Siswa berdiskusi dengan kelompok, dan kemampuan siswa dalam proses bekerjasama dalam pembelajaran kooperatif learning. Berdasarkan hasil observasi aktivitas siswa dalam kegiatan belajar mengajar pada siklus II perteman I diperoleh jumlah rata-rata presentase 3,53 dan kategori sangat baik. Berdasarkan hasil tabel 4.7 menunjukkan aktivitas siswa dalam kegiatan 
belajar mengajar pada siklus II perteman I diperoleh jumlah rata-rata presentase 3,53 dan kategori sangat baik. Pengukuran aktifitas guru pada siklus II selama pelaksanaan proses pembelajaran yang diukur oleh mitra kolaborator melalui proses pengamatan terhadap aktifitas guru dalam kegiatan mengajarnya dilakukan dengan lembar observasi. Observasi meliputi observasi sikap siswa. Hal tersebut diakukan untuk mengukur ketercapaian tujuan bagian dari sikap siswa terhadap pelajaran IPS, dan memberikan dorongan sikap positif bagi pembelajaran siswa dikelas. Untuk tercapainya tujuan pendidikan seharusnya sistem pendidikan tidak hanya mengutamakan pada aspek pengetahuan tetapi juga pada aspek sikap, karena aspek sikap sama pentingnya dengan aspek pengetahuan dan ketrampilan ${ }^{7}$. Menunjukkan aktivitas guru dalam kegiatan belajar mengajar pada siklus II pertemuan I berada pada presentase $77,5 \%$. Pada siklus II pertemuan II diatas, diperoleh presentase rata-rata 82,5\% atau berada pada kriteria Baik sesuai dengan kriteria yang telah ditetapkan dalam penelitian ini. Dengan demikian aktivitas guru dalam kegiatan belajar mengajar telah terlaksana.

\section{HASIL DAN DISKUSI}

Berdasarkan hasil penelitian yang telah dilaksanakan, hasil partisipasi peserta didik dari siklus I diperoleh persentase rata-rata sebesar 58,33\% dengan menurut hasil perolehan menurut observer masih dikategorikan kurang. Selanjutnya pada pelaksanaan tindakan siklus II mengalami peningkatan, dengan persentase rata-rata sebesar 91,67\% dan berada pada kategori sangat baik. Data tersebut menunjukan bahwa terjadi peningkatan 33,34 \% dari siklus I ke siklus II. Artinya terjadi peningkatan aktivitas siswa dalam proses pembelajaran yang dilaksanakan sudah dikatakan berhasil atau berada pada indikator yang telah ditetapkan.

\section{Hasil Aktivitas Guru dalam Pelaksanaan Pembelajaran}

Terjadi peningkatan aktivitas pembelajaran guru pada pelaksanaan siklus II. Adapun peningkatan yang terjadii dikarenakan guru telah melaksanakan proses pembelajaran sesuai dengan rambu-rambu dalam kegiatan belajar mengajar. Peningkatan aktivitas guru dalam mengajar pada mata pelajaran IPS dengan menggunakan metode

${ }^{7}$ Ulfa, I. R. (2019). Implementasi Instrumen Penilaian Sikap di SDN Gunungsaren Bantul. PALAPA, $7(2), 50-65$. 
Kooperatif Learning di kelas IV SDN Jatiasih juga mengalami peningkatan ${ }^{8}$. Pada siklus I diperoleh persentase rata-rata sebesar 62,5\% dan berada pada kategori cukup. Kemudian mengalami peningkatan pada siklus II dengan persentase rata-rata sebesar 82,5\% berada pada kategori baik. Melihat hasil pencapaian tersebut yang menunjukan bahwa hasil partisipasi guru dalam proses pembelajaran dari siklus I ke siklus II menunjukan adanya peningkatan yang cukup berarti dan telah tercapai sesuai dengan indikator kinerja yang di tetapkan dalam penelitian atau berada pada kategori Baik. Berdasarkan hasil yang diperoleh pada hasil belajar siswa, aktivitas siswa dan aktivitas guru pada siklus II menunjukan peningkatan yang signifikan hal ini disebabkan karena penggunaan metode Kooperatif learning telah terlaksana dengan baik dan efektif dalam proses belajar mengajar IPS di kelas IV SD Negeri Jatiasih. Dengan demikian bahwa penelitian dinyatakan berhasil.

\section{Hasil Belajar Siswa}

Tolak ukur yang penting dalam proses belajar mengajar untuk meningkatkan kemampuan pemahaman melalui Pembelajaran pada pembelajaran IPS adalah melalui metode Kooperatif learning di kelas di kelas IV SDN Jatiasih. Sebab melalui metode kooperatif learning dapat tercapai tujuan pembelajaran yang telah dirumuskan sebelumnya dan terciptanya pembelajaran yang efektif, inovatif dan menyenangkan? Berdasarkan hasil analisis data dalam penelitian ini meliputi peningkatan kemampuan pemahaman melalui Pembelajaran yang dilakukan pada akhir setiap siklus juga mengalami peningkatan. Hal tersebut, dapat diartikan pembelajaran yang sesuai dengan tujuan yang direncnakan sebelumnya ${ }^{10}$. Dari siklus I ke siklus II memperlihatkan adanya peningkatan yang cukup berarti yakni dari rata-rata hasil belajar siklus I sebesar $67 \%$ naik menjadi $76 \%$ pada siklus II atau mengalami peningkatan sebesar $9 \%$. Akan halnya pada ketuntasan hasil belajar secara klasikal dari $68,75 \%$ pada siklus I meningkat menjadi $87,5 \%$ pada siklus II atau

\footnotetext{
8 Munawaroh, R., Subali, B., \& Sopyan, A. (2012). Penerapan Model Project Based Learning dan Kooperatif Untuk Membangun Empat Pilar Pembelajaran Siswasmp. UPEJ Unnes Physics Education Journal, 1(1).

9 Widiyarto, S., \& Ati, A. P. (2019). Pengaruh Metode Snow Ball Throwing Dan Minat Belajar Terhadap Keterampilan Menulis Kalimat Argumen Siswa Smk Insan Mulia Kota Bekasi. Judika (Jurnal Pendidikan Unsika), 7(1), 36-45

10 Ilham, I.,dkk (2018). Peningkatan Hasil Belajar Tanah dan Pupuk Melalui Model Pembelajaran Kooperatif Tipe Learning Together pada Siswa Kelas X Agronomi SMK Negeri 1 Marioriwawo Soppeng. Jurnal Pendidikan Teknologi Pertanian, 1(1), 30-37.
} 
mengalami peningkatan sebesar 18,75\%. Sedang untuk daya serap klasikal pada siklus I diperoleh 67,5\% meningkat pada siklus II menjadi 76,04. Artinya bahwa hasil yang diperoleh tersebut telah memenuhi kriteria ketuntasan belajar siswa secara klasikal sebagaimana yang telah ditetapkan pada indikator penelitian ini yaitu sebesar $70 \%$ dan ketuntasan hasil belajar individu sebesar 70 .

Berdasarkan hasil yang di capai oleh siswa tersebut, maka dapat dikatakan bahwa kemampuan pemahaman siswa menggunakan Pembelajaran, pada pembelajaran IPS dapat ditingkatkan melalui Metode Kooperatif learning di kelas IV SD Negeri Jatiasih Bekasi.

\section{KESIMPULAN}

Kesimpulan yang dapat ditarik dari Penelitian Tindakan Kelas (PTK) ini adalah bahwa melalui metode kooperatif learning dapat meningkatkan hasil belajar IPS pada materi ASEAN. Hal ini berdasarkan pada perolehan hasil belajar dan observasi aktivitas guru dan siswa yang mengalami peningkatan secara signitifan. Hasil tes belajar tindakan siklus I, diperoleh ketuntasan belajar klasikal sebesar 67,75\% daya serap klasikal diperoleh sebesar 66,5\% dengan persentase nilai rata-rata sebesar $67.47 \%$. Pada hasil tes belajar siklus II mengalami peningkatan, dimana perolehan ketuntasan belajar klasikal sebesar 87,5\%, daya serap klasikal sebesar 76,04\% dengan persentase nilai rata-rata sebesar $76 \%$.

\section{SARAN}

Pelajaran IPS yang selama ini hanya menggunakan strategi dan metode yang sudah ada, diperlukan upaya guru untuk merancang dan mendesain metode pembelajaran yang inovatif, efektif, bermakna dan menyenangkan untuk siswa. Salah satu metode yang dapat digunakan dalam meningkatkan kemampuan pelajaran IPS adalah melalui metode kooperatif learning. Metode ini dapat dikombinasikan denan metode lain, dan dapat menggunakan pendekatan pembelajaran yang bervariasi. Upaya guru untuk menggunakan PTK dapat menghasilkan teribosan baru bagi pembelajaran pelajaran IPS di sekolah dasar. 


\section{DAFTAR PUSTAKA}

Aminul Hayat, 2004. Matematika Untuk SMA Kelas X, Bandung : Regina Anita Lie, 2008. Cooperative Learning.Jakarta : PT Gramedia.

Arends, R. I. 2008. Learning To Teach. New York : McGraw Hill Companies. Husein Tampomas, 2004. Seribu Pena Matematika SMA untuk Kelas X, Jakarta : Erlangga.

Ibrahim, M. 2005. Asesmen Berkelanjutan. Surabaya: Unesa University Press Juita, H. R., \& Widiyarto, S. (2019, March). The Effectiveness of Cooperative

Learning Methods: A case study of writing learning at Junior High School. In Second Conference on Language, Literature, Education, and Culture (ICOLLITE 2018). Atlantis Press.

Nurkencana, 1990. Evaluasi Hasil Belajar. Surabaya: Usaha Nasional.

Nurlailatul Himah, 2008. Penerapan Model Pembelajaran Kooperatif Tipe Jigsaw dalam Meningkatkan Prestasi Belajar Siswa Kelas VII B MTs Negeri 3 Mataram Tahun

Pelajaran 2007/2008. Skripsi. Mataram. IKIP

Oemar Hamalik, 2008. Proses Belajar Mengajar. Jakarta : Bumi Aksara. , 2008. Kurikulum dan Pembelajaran.Jakarta : Bumi Aksara.

Pupuh Fathurrohman, dkk, 2007. Strategi Belajar Mengajar.Bandung : Refika Aditama.

Ratmaje Syahdan, 2009. Peningkatan Aktivitas Belajar dan Hasil Belajar Melalui Penerapan

Model Pembelajaran Kooperatif Tipe Jigsaw Pada Mata Pelajaran IPA Biologi Kelas XI

Semester I Di SMA Negeri 7 Mataram Tahun Pelajaran 2009/2010. Skripsi.

Mataram. IKIP.

Roestiyah N.K, 2008. Strategi Belajar Mengajar. Jakarta : Rineka Cipta.

Slameto, 2003. Belajar dan Faktor-Faktor yang Mempengarubinya. Jakarta : Rineka Cipta

Suhaedi, 2009. Penerapan Model Pembelajaran Kooperatif tipe Jigsaw dalam PeningkatanMotivasi dan Ketuntasan Belajar Siswa Kelas VII Pada Mata Pelajaran

Biolgi SMPN 11 Mataram Tahun Pelajaran 2008/2009. Skripsi. Mataram. IKIP Suharsimi Arikunto, dkk. 2008. Penelitian Tindakan Kelas. Jakarta : Bumi Aksara. 2006. Prosedur Penelitian Suatu Pendekatan Praktik. Jakarta: Rineka Cipta.

2003. Dasar-Dasar Evaluasi Pendidikan. Jakarta: Bumi Aksara

Syaiful Bahri Djamarah, 1994. Prestasi Belajar dan Kompetensi Guru. Surabaya: Usana Offset Printing.

Sagala, Syaiful.2003. Konsep dan Makna Pembelajaran. Bandung: Alfabeta

Sugiono. (2010). Metode Penelitian Kuantitatif, Kualitatif. Bandung: Alfabeta

Sudjana, dkk. 1989. Pedoman Praktek Mengajar. Bandung; Depdikbud

Winkel, WS. 1996. Psikologi Pengajaran. Edisi Revisi. Jakarta: Grasindo

Fathani Abdul Halim, 2009. Matematika Hakikat \& Logika.Jogjakarta : Ar-ruzz Media.

Suprijono Agus, 2009. Cooperative Learning. Yogyakarta : Pustaka Pelajar 
Ulfa, I. R. (2019). Implementasi Instrumen Penilaian Sikap di SDN Gunungsaren Bantul. PALAPA, 7(2), 50-65. 2008. Psikologi Belajar.Jakarta : Rineka Cipta.

Yusuf. 2003. "Kualitas Proses dan Hasil Belajar Biologi Melalui Pengajaran dengan Model Pembelajaran Kooperatif Tipe Jigsaw Pada Madrasah Aliyah Ponpes Nurul Haramain Lombok Barat NTB.” Thesis, Surabaya: Universitas Negeri Surabaya.

Widiyarto, S., \& Ati, A. P. (2019). Pengaruh Metode Snow Ball Throwing Dan Minat Belajar Terhadap Keterampilan Menulis Kalimat Argumen Siswa Smk Insan Mulia Kota Bekasi. Judika (Jurnal Pendidikan Unsika), 7(1), 36-45 